\title{
Distributive justice and regenerative medicine
}

\author{
John Gardner*,1 \\ 'Department of Sociology, School of Social Sciences, Monash University, W414 Menzies Building, 20 Chancellors Walk, Clayton, \\ Melbourne, 3800, Australia \\ * Author for correspondence: john.gardner@monash.edu
}

Many countries have identified regenerative medicine as a strategic priority, and have thus launched a range of initiatives to facilitate innovation in the field. This perspective paper argues that several initiatives involve resource distributions that could impinge on widely accepted egalitarian notions of fairness and justice that underpin current healthcare systems. Specifically, this paper focuses on five initiatives, and argues that these initiatives reflect a largely unacknowledged utilitarian perspective on distributive justice. The intention of this paper is not to argue against these initiatives, but rather to stimulate an open discussion on what qualifies as a just and fair system of resource distribution, so that the regenerative medicine field can responsibly deliver on its clinical potential.

First draft submitted: 15 March 2017; Accepted for publication: 7 July 2017; Published online: 2 November 2017

Keywords: bioethics $\bullet$ distributive justice $\bullet$ policy $\bullet$ regulation $\bullet$ reimbursement

In the late 1990s and for much of the 2000s, policy activity relating to regenerative medicine (RM) was focused on the ethical utilization of human-derived tissue. In the last 10 years, however, there has been a notable change in emphasis: 'facilitating translation from the bench to the bedside', and indeed 'accelerating' innovation, have become the primary concerns for policy makers in several countries [1]. In the UK, this is exemplified in multiple reports on the UK's capacity to foster an RM industry, including the reports from both the House of Lords and House of Commons Science and Technology Committees, and the government-supported RM Expert Group [2,3]. The reports have proposed a range of initiatives for facilitating innovation in the field of RM, including the establishment of new collaborative research programs, adjustments to commissioning systems and regulatory arrangements, and the establishment of specialist centers for providing RM therapies. Many initiatives have already been launched, an obvious example being the establishment of the UK Cell and Gene Therapy Catapult in 2012 and which is now a major actor in the field [4]. In this paper, I will illustrate that several of the enacted and proposed innovation-facilitative initiatives involve resource distributions that 'could' impinge on widely accepted egalitarian notions of fairness and justice that underpin current healthcare systems in Europe. Specifically, I focus on five initiatives: the establishment of innovation-accelerator agencies; conditional licensing and risk-sharing schemes; the value-based pricing approach in health technology assessment (HTA); the provision of ear-marked funds to commission innovative therapies; and the proposed establishment of specialist treatment centers. The intention of this paper is not to argue against these initiatives - it may be that such initiatives are necessary, and as I will show in the following section, there are multiple perspectives on distributive justice which have also influenced healthcare systems, and which could provide justification for such measures. Rather, the intention is to stimulate an open (and ideally ongoing) discussion on what qualifies as a just and fair system of resource distribution, so that the RM field can responsibly deliver on its clinical potential. The RM field is currently at a critical juncture. New innovation-facilitative infrastructures are being or will soon be forged that, according to some commentators, are representative of a major transformation in the organization of biomedical $R \& D$ and healthcare provision more generally [5-7]. It is vital that the potential repercussions of proposed initiatives are carefully considered before they bring about what could become obstinate institutionally embedded infrastructures. Deliberations on redistributive justice within promissory biomedical projects such as RM are especially pertinent in the current political context 
of the UK: in effect, resources have been redirected from services that provide much-valued assistance to people in the present day.

In the following section, I provide a brief overview of theories of distributive justice. I focus predominately on the egalitarian and utilitarian understandings of distributive justice, briefly comparing them with libertarian theories, and I illustrate how each of these have influenced various aspects of healthcare provision and governance in several countries. In the third section of this paper, I use these theories of distributive justice as an analytical frame for examining each of the five innovation-facilitating initiatives. I illustrate that these initiatives reflect a largely unacknowledged utilitarian perspective on resource distribution, in which value is promissory in nature and broadly equated to health and national prosperity. Some debates surrounding these initiatives, however, illustrate that egalitarian sentiments have also been influential. In the 'Conclusion \& future perspective' section, I outline specific issues that require ongoing discussion with a range of stakeholders, so that the field as a whole can responsibly deliver on its significant promise.

\section{Theories of distributive justice}

The rising costs of health services and vast inequalities in access to healthcare illustrate the importance of justice as an ethical concern in biomedicine. Indeed, justice has been championed as one of the four moral principles within Beauchamp and Childress' foundational "Principles of Biomedical Ethics" [8], and their description of distributive justice provides a useful starting point here. Distributive justice, as they define it, refers to:

"Fair, equitable and appropriate distribution determined by justified norms that structure the terms of social cooperation. Its scope includes policies that allot diverse benefits and burdens such as property, resources, taxation, privileges and opportunities" [8].

This formal principle is often articulated using the words attributed to Aristotle: "Equals must be treated equally, and unequals must be treated unequally". It is of course when it comes to identifying the substantive dimensions (i.e., what is actually meant by 'equal' and 'appropriate distribution') that different theories of distributive justice become apparent. Differing positions, as the above extract suggests, are supported by specific social norms that reflect specific political-philosophical traditions [9].

Arguments from egalitarian theories of justice have been particularly influential in shaping and justifying healthcare provision. In general, egalitarian theories of distributive and social justice presume that an individual's health status is determined by the 'lottery of life,' and is, then undeserved. Additionally, egalitarian theories abide by the fair opportunity rule that states that:

"No persons should receive social benefits on the basis of undeserved advantageous properties. . . and that no person shall be denied social benefits on the basis of underserved disadvantageous properties" [9].

Advocates of this position have argued that healthcare provision should therefore be organized in such a way that it will enable each individual to gain access to a normal range of opportunities within society. This, in turn, means that healthcare resources may be unequally distributed, so that those individuals with an (undeserved) poor health status receive additional support [10]. This argument has had widespread appeal and many existing healthcare systems specifically those that proclaim to provide universal healthcare - are justified with an egalitarian position. A core principle of the National Health Service (NHS) England Constitution, for example, is that "access to NHS services is based on clinical need, not an individual's ability to pay" [11]. Services are free of charge, and those individuals with greater clinical need (such as a chronic neurological condition) will ideally receive a greater share of health resources.

In reality, however, it is not possible to allocate resources purely according to clinical need. Health resources are severally constrained and the clinical benefit of new interventions may be, at least initially, highly uncertain. For these reasons, governance mechanisms such as HTA agencies determine which clinical services will be provided within a healthcare system. HTA authorities such as the UK's NICE typically rely on systematic assessments of cost-effectiveness: a cost/benefit profile for a candidate therapy is assessed its relation to existing standards of care. Such gate-keeping mechanisms (which are common in many countries and are currently being advocated by the EU Commission) enshrine a 'utilitarian approach' to resource distribution [12]. The key principle of utilitarian approaches to distributive justice is that resources should be distributed in such a way that maximizes value (i.e., in such a way that produces the most utility). In healthcare governance, some HTA agencies such as NICE typically use Quality-Adjusted Life Years (QALYs) to represent value/utility, and decisions to commission a therapy will be guided by a determination of its cost per QALY profile. Determining what exactly 'counts' as value/utility in 
an utilitarian approach is of course up for contestation, and the use of QALYs to represent value/utility has been heavily criticized [5]. As explored further on, proponents of a value-based pricing approach have argued that value should be defined more broadly [13].

Many contemporary healthcare systems, then, enshrine an egalitarian approach in their attempt to provide universal care, and governance mechanisms within these systems often deploy methods that are primarily - but not exclusively - utilitarian. Other healthcare systems, however, also have significant elements that align with a 'libertarian' interpretation of distributive justice. The principle concern in libertarian understandings of justice is to protect and affirm the liberty and individual rights of citizens, and hence, the free market is championed as the acceptable means of distributing resources [14]. In a pure form of libertarianism, taxing citizens so that individuals with undeserved, disadvantageous health statuses can enjoy a normal share of opportunities would be deemed unjust. Advocates of libertarianism, however, often support healthcare systems based on insurance that may entail utilitarian or egalitarian redistributions, provided that insurance is voluntarily and privately purchased. Conventionally, the US healthcare system has been aligned with a libertarian approach, but the tax-funded medicare and medicaid schemes do enshrine the egalitarian sentiment that some basic services should be made available to specific disadvantaged groups [8]. The enactment of the Patient Protection and Affordable Care Act (Obamacare) in 2010 can be seen as an attempt to further embed egalitarian distributive justice within the system [15].

There are, then, multiple positions on the substantive dimensions of distributive justice, and current healthcare systems tend to represent points at which different positions - egalitarian, utilitarian and libertarian - are articulated and aligned. Just how they are aligned and coordinated depends of course on the wider sociocultural and political context, and as the contemporary debates around Obamacare illustrate, this can be a prolonged process characterized by considerable conflict. Indeed, issues around distributive justice are often openly debated during major healthcare reform. Biomedical innovation can also entail a reshuffling of resource distribution mechanisms however, discussions on the repercussions for distributive justice tend to be side-lined in favor of other important ethical concerns. The next section examines some of the translational initiatives in RM and their repercussion for distributive justice.

\section{Specific justice issues in RM}

A diverse range of emerging technologies and techniques fall under the umbrella of 'regenerative medicine' and use of the term has tended to vary somewhat [16]. Nevertheless, 'regenerative medicine' has been named as a strategic priority by governments such as Canada, UK, Japan and various US states including New York, Massachusetts, California and others [17]. These governments have identified RM as having considerable clinical and economic potential, and have thus set about facilitating the emergence of a 'health and wealth' generating RM industry $[18,19]$. Significant financial resources have been mobilized to do this - the State of California raised US $\$ 3$ billion from bonds to fund the Californian Institute for Regenerative Medicine (CIRM). Such initiatives align with a more general focus in R\&D policy on facilitating the translation of promising developments in the life sciences into clinically useful tools. Mittra has argued that this focus is bringing about a major transformation in the 'ecosystem' of biomedical innovation and healthcare provision: new agencies (such as CIRM) have been established, new interdisciplinary collaborations are emerging, novel regulatory frameworks - such as the EMA's Advanced Therapy Medicinal Products (ATMP) framework - have been negotiated, and other changes to governance structures are also being considered [5]. There is, then, a major transformation in the way in which biomedical resources are distributed and governed. Here, I discuss five specific proposed or enacted initiatives within this emerging ecosystem.

\section{State-supported innovation-accelerator agencies: socialized risk, private profit}

The most significant initiatives to facilitate innovation within RM have been the establishment of so-called innovation-accelerator agencies. Agencies similar to the CIRM have been established in several countries: the Centre for the Commercialization of Regenerative Medicine (CCRM) was launched in Canada in 2011, and the UK's Cell and Gene Therapy Catapult (CGTC) was launched in 2012 with 70 million GBP in government funding. The aim of these centers is to facilitate the establishment of health and wealth-generating, globally competitive RM industries. The CGTC, for example, describes itself as "a center of excellence in innovation, with the core purpose of building a world-leading cell and gene therapy sector in the UK as a key part of a global industry" [20]. The agencies, then, are concerned with facilitating innovation that specifically involves commercialization and market creation, and they have been structured accordingly. The CCRM, for example, is a public-private partnership that involves representatives from Pfizer, GE Healthcare, Athersys and other pharma and biotech companies of various 
sizes. Similarly, the CGTC advisory board includes representatives from GlaxoSmithKline, GE Healthcare and AstroZeneca, and their boards of directors have extensive experience in life science industries. The CCRM and CGTC also contain experts on intellectual property, business modelling, regulation and reimbursement hurdles, and on manufacturing and logistics, which can work with academics, clinicians and companies to develop products for an envisaged market [4].

Via such agencies, industry representatives together with other experts in the field are directing public funding toward the commercialization of RM products and techniques. Promising products are being 'de-risked' in order to attract investment from large pharma, venture capital and other investors. In effect, public resource is being used to produce assets and commodities that will be privately owned. It is also expected that many of these products will eventually be commissioned by public healthcare systems such as the NHS, probably at a significant price in order to cover the high cost of cell or gene therapy manufacturing. Tax payers, then, will partially cover the cost for developing therapies, and they will collectively commission these therapies.

From an egalitarian perspective, this arrangement of distributing public funds may appear to be unjust. Taxpaying citizens share the financial risk of commercial failure, but do not directly financially benefit from the commercial success of products. The direct financial rewards would be shared among industry and investors. It appears, then, that innovation-accelerator agencies are consolidating a system in which there is an unequal distribution of potential benefits and opportunities. An egalitarian position might state that such public funds would be better directed toward social services that can provide those with undeserved disadvantaged properties (chronic illness, or disabilities) with the normal share of social benefits.

What we see, however, is that justifications for the innovation-accelerator agencies tend to reflect an unacknowledged utilitarian perspective on distributive justice. In the UK, the establishment of the CGTC has been justified as the most expeditious way of bringing about a health and wealth-generating industry [21]. It is positioned, in other words, as a means of maximizing the value of existing public funds, and also as way of maximizing the UK's strong biomedical science base. The value is promissory, and it is equated with benefits such as new cures, high-paying jobs and an overall increase in national wealth and prosperity. Government supported innovation-accelerator agencies align with what Mazzucato has influentially described as the Entrepreneurial State [22]. The ideal role of the state, she argues is to foster innovation, and it can do so most efficiently by stimulating specific innovation dynamics, such as collaborations between industry and academia, assisting small- and medium-sized enterprises (SMEs) and removing specific innovation hurdles. Accordingly, innovation-facilitating work should be delegated to experts in the field (including industry representatives) rather than being undertaken by politicians or bureaucrats, who would lack the time and expertise to understand the challenges 'on the ground'. David Willetts, the then Minister for Universities and Science, used these arguments when announcing the UK's policy on fostering RM in 2013 [23].

The establishment of agencies such as the CGTC and the CCRM illustrate that a particular utilitarian approach to distribution is becoming entrenched in the emerging RM ecosystem. Interestingly, however, Mazzucato argues that such an approach is, on its own, unjust. A fair and just 'Entrepreneurial State' is also guided by egalitarian sentiment: tax payers, she argues, should directly financially benefit from the successful commercialization of a product by receiving a share of the profits. Mazzucato makes several recommendations on how this can be achieved - these are briefly addressed in the final section.

\section{Conditional approval \& risk-sharing: paying for predicted efficacy}

Governance reform has been the subject of ongoing discussion within the field of RM [24-27]. Commentators have suggested that existing regulatory and HTA frameworks, which emerged to govern drug- and device-based therapies, are poorly suited to accommodating RM products and techniques, and thus represent a formidable hurdle to bring new therapies to the clinic [28]. Specifically, the concern is that these governance mechanisms (including the ATMP framework) require an evidence profile that is too onerous to produce for products and techniques that are highly novel [29]. Much needed investment will thus be directed elsewhere. In response, conditional/provisional marketing authorization schemes have been established such as the EMA's Priority Medicines (PRIME) scheme, and risk-sharing reimbursement arrangements have been launched or are being considered [30]. The former, such as Japan's conditional authorization scheme, permits RM products to be provisionally placed on the market earlier in the clinical trials process - after the demonstration of safety, and when efficacy can be predicted rather than demonstrated [31]. Risk-sharing schemes are an arrangement in which the cost of providing the therapy is split over two or more parties. This means that one party does not have to take on the full burden of financial risk for promising therapies that have uncertain clinical benefit profiles. 
Distributive justice is highly relevant here, given that such schemes involve a reshuffling of risk and potential benefits among different groups. There are current arrangements in several countries where the health commissioners only reimburses a company for those patients who meet certain clinical milestones. In Italy, for example, GlaxoSmithKline will be reimbursed only for those patients who are cured of their adenosine deaminase severe combined immunodeficiency with the gene therapy product, Stremvelis (which costs US $\$ 665,000$ per patient) [32]. In such schemes, strained healthcare systems are spared additional financial risk (and companies are discouraged from exaggerating the clinical potential of their products). From an egalitarian perspective, such risk-sharing arrangements would clearly be more favorable than other proposed schemes. One proposed scenario is that patients themselves pay for a proportion of the cost of therapies, particularly during conditional approval.

This arrangement currently exists in Japan. The Regenerative Medicine Promotion Act in 2013 brought about regulatory reform including provisional approval for therapeutic cell products. Therapies can therefore be made available to patients before their efficacy has been proven [33]. Under current reimbursement arrangements, $70 \%$ of the cost of these yet-to-be-deemed efficacious therapies is covered by national health insurance and $30 \%$ is covered by the patient, potentially placing high-cost therapies out of the reach of low-income citizens [31]. The financial hurdle presented to lower income citizens for accessing potentially revolutionary treatments would not be justifiable within an egalitarian approach. Additionally, the system has also been criticized for "essentially. . . asking patients to pay for the privilege of serving as the subject of medical experiments" [34].

Again, a utilitarian logic appears to underlie such initiatives. For Japan, the Regenerative Medicine Promotion Act is an attempt to build upon the ground-breaking work of Shinya Yamanaka and establishe itself as a world leader in induced pluripotent stem cells (iPSC) technology [35]. Consequently, the conditional licensing of cell therapies is perceived as an expeditious means of promoting innovation in this area by attracting investment. As with the utilitarian logic that underlies the establishment of the innovation accelerator agencies, 'value' is promissory in nature and relates to both clinical and economic benefit, and also national prestige.

\section{Value-based pricing in HTA}

Several reports into the UK's capacity to support an emerging RM industry have explicitly identified the QALYbased approach of NICE as a significant challenge. Many RMs will target diseases with unmet clinical need and with a large burden of illness - not just on the afflicted individual, but on careers, families and indeed wider society. Some treatments will also, however, have high-upfront costs. A QALY-based approach, it is argued, would fail to fully account for the burden of disease and would unfairly disadvantage these high-cost treatments [5]. The value-based pricing (VBP) approach was identified as a more suitable alternative. At one stage, NICE was expected to formally adopt the VBP approach, but after some debate, it has retained the QALY-based approach for the meantime. The implications of these two approaches on distributive justice have, then, been discussed in some depth [36], so I will only briefly recount them here.

Advocates of the VBP have argued that the QALY is too narrow: it fails to capture the impact of an intervention on carers, other social services and employment participation, for example [5]. In effect, advocates of VBP are arguing that the QALY-based approach is a flawed means of operationalizing a utilitarian approach to distributive justice. Indeed, some of the arguments against VBP reveal that current HTA methodologies are also supported by egalitarian sentiments: the problem with VBP, it is argued, is that it would unfairly disadvantage interventions for certain groups such as the elderly whose potential social utility (in terms of participation in employment, dependence on carers, etc.) would likely be deemed less than that of others [36]. While such a system may be justified with a purely utilitarian perspective, it would be deemed unjust in an egalitarian perspective, since these groups would be denied social benefits on the basis of their undeserved disadvantageous properties.

For the time being, it seems that HTA in the UK represents a space in which some egalitarian sentiment has explicitly been reaffirmed in the face of a more general surge in utilitarian arguments.

\section{Privileging innovative therapies with ear-marked funding}

Concerns over existing HTA systems have also led to the establishment of specific reimbursement funds for therapies that are deemed to be especially 'innovative'. Again, the justification of these is that highly innovative therapies are unfairly disadvantaged in conventional HTA cost-effectiveness analyses due to the level of evidence required. The specialist 'innovation' schemes require a less demanding body of evidence, and they provide funding for the commissioning of a therapy on the expectation that additional evidence will be generated in due course [37]. RMs are likely to make use of these initiatives, and indeed TiGenix attempted to make use of this pathway for their 
ChondroCelect product with mixed success: ChondroCelect was considered for inclusion in The Netherlands' 'Beleidsregel - Dure Geneesmiddelen' scheme for innovative new medicines, and it was reimbursed in Germany via the 'Neue Untersuchungs und Behandlungsmethode' (NUB - New research and treatment methods) scheme [38]. In the UK, the advanced-therapies-manufacturing taskforce has suggested that the government consider establishing a similar fund, especially for cell and gene therapies. Such a fund would be time-limited and dedicated to the early procurement of the therapy within the NHS, enabling the collection of data to permit a thorough cost-effectiveness analysis.

These schemes, therefore, create an alternative, less onerous pathway to the clinic for therapies that are deemed to be particularly innovative. Some proposed schemes will involve a significant concentration of resources around these pathways: the recent call to create a formal 'accelerated access pathway' within the NHS is an example of this [39]. Once again, we see that promissory expectations - the promise of future clinical and economic pay-off are shaping the allocation of resources. The ATMP Taskforce, for example, has emphasized the importance of a specialist cell and gene therapy reimbursement fund specifically for encouraging further investment and innovation in the field [37]. Advocates have also, however, drawn on egalitarian arguments as justification for these specialist funds $[36,37]$. The narrative of these arguments is that individuals with unmet clinical need are unfairly disadvantaged compared with those who have treatment options, and that specialist reimbursement funds and accelerated access pathways will enable these patients to more quickly access promising new therapies. Accordingly, it is implied that the redistribution of resources to target unmet clinical need (rather than to maximize utility) is ethically justified.

The Nuffield Council on Bioethics has made this argument in relation to other medical technologies (such as deep brain stimulation) [40], and indeed the same argument can be used to justify any promising technology or technique that will potentially treat unmet clinical need. From this egalitarian perspective, whether or not a therapy is deemed a 'RM' (or a 'cell and gene therapy') is irrelevant and should not be a criterion for allocating specialist funds for accelerating access. From this perspective, schemes that make no distinction between therapy types would be more justifiable than those that are specifically for cell and gene therapies - such as that proposed by the ATMP Taskforce.

\section{Specialist centers for cell \& gene therapy treatments}

In the UK, both the RM Expert Group report and the ATMP Taskforce report have recommended the establishment of specialist clinical centers for delivering cell and gene therapy treatments [2]. This will involve consolidating resources at specific clinical sites that are already leading the field in developing and trialing RMs. These will be hospitals which have access to GMP facilities and that are providing specialized hematological services, and which, then, have the necessary experience in handing live tissues and cells. The ATMP Taskforce has suggested that the government devote $£ 30$ million to the establishment of this coordinated national network of 'Cell and Gene Therapy Centers.' The fund would be administered by Innovate UK and would be awarded competitively [37]. The centers would represent a partnership between the NHS and industry, in which the NHS provides clinical expertise and patients while industry provides further investment and manufacturing expertise.

There is a strong utilitarian argument underlying the proposal. For example, the taskforce argues that the establishment of such centers will provide a degree of stability that will enable companies and other stakeholders to develop infrastructures for supply chains, data-gathering and manufacturing, and to develop and test new business models [37]. The up-front investment, in other words, is an efficient way of facilitating the emergence organizational forms that would constitute a health-creating industry.

Consolidating resources for high-cost, highly-specialized therapies at a few specific clinical centers is commonplace within the UK and elsewhere, especially for therapies targeting rare diseases. Inevitably, however, there is a tension between a utilitarian push to cost-effectively support a few specialist centers, and an egalitarian sentiment to avoid exacerbating regional inequalities. These inequalities may relate to ease of access for patients and economic benefits for communities that provide support services for such centers. Many RM therapies on the near horizon will be targeting rare diseases, and it is common sense that one or two specialist centers will be identified to deliver these for large geographic regions. However, in the longer term when new treatments are hopefully approved for widespread chronic conditions, egalitarian considerations will become more pressing when considering centers for delivery. Regional inequalities relating to ease of access have already been identified as a major problem within the UK [41], and it is possible that the emerging RM industry could exacerbate this. 
Table 1. Summative table of innovation initiatives within the regenerative medicine field, indicating the issues they raise in relation to egalitarian and utilitarian perspectives of distributive justice.

\begin{tabular}{|c|c|c|}
\hline \multirow[t]{2}{*}{ Regenerative medicine innovation initiative } & \multicolumn{2}{|c|}{ Issues relating to egalitarian and utilitarian notions of justice } \\
\hline & Egalitarian & Utilitarian \\
\hline State-sponsored innovation-accelerator agencies & $\begin{array}{l}\text { These may conflict with EGAL perspectives, as tax } \\
\text { payers share financial risk for developing privately } \\
\text { owned products and assets }\end{array}$ & $\begin{array}{l}\text { Reflects UTIL sentiment in which 'value' is promissory } \\
\text { and equated with future national 'health and wealth' }\end{array}$ \\
\hline Conditional approval and risk sharing & $\begin{array}{l}\text { Arrangements in which patients pay partial costs for } \\
\text { provisionally approved products conflict with EGAL } \\
\text { notions } \\
\text { Arrangements in which manufacturers and healthcare } \\
\text { providers share risk, such as 'money-back guarantee' } \\
\text { may align with EGAL notions }\end{array}$ & $\begin{array}{l}\text { Reflects UTIL sentiment in which 'value' is promissory } \\
\text { and equated with future national 'health and wealth' }\end{array}$ \\
\hline Value-based pricing in health technology assessment & $\begin{array}{l}\text { These conflict with EGAL notions, as some } \\
\text { 'undeserved' traits of individuals (such as older age) } \\
\text { are devalued }\end{array}$ & $\begin{array}{l}\text { Broadens understanding of 'value' in an UTIL attempt } \\
\text { to better align spending/price with value }\end{array}$ \\
\hline $\begin{array}{l}\text { Privileging innovative therapies with ear-marked } \\
\text { funding }\end{array}$ & $\begin{array}{l}\text { Schemes that facilitate access to unmet clinical need } \\
\text { may align with EGAL understandings, provided they } \\
\text { do not favor RM therapies over other promising } \\
\text { therapies }\end{array}$ & $\begin{array}{l}\text { Also reflects UTIL sentiment in which 'value' is } \\
\text { promissory and equated with future national 'health } \\
\text { and wealth' }\end{array}$ \\
\hline Specialist centers for cell and gene therapy treatments & $\begin{array}{l}\text { Tension between UTIL drive to centralize resource at } \\
\text { key specialist centers, and EGAL sentiment to avoid } \\
\text { exacerbating regional inequalities }\end{array}$ & $\begin{array}{l}\text { UTIL drive to create stability to foster supporting } \\
\text { infrastructure development } \\
\text { Reflects UTIL sentiment in which 'value' is promissory } \\
\text { and equated with future national 'health and wealth' }\end{array}$ \\
\hline
\end{tabular}

\section{Conclusion \& future perspective: balancing utilitarianism with egalitarianism}

In their exploration of the political economy of RM, Salter and colleagues have argued that we are seeing is an example of a particular governance style [42]. This is a governance style in which the state secures the allegiance of powerful groups such as academics and scientists (and their institutions), public servants and importantly, industry [43]. This characterization may appear simplistic, but it does highlight the necessity of exploring issues relating to distributive justice: vast resources are being directed toward projects - from which some groups directly benefit - that are still largely promissory in nature. In the UK, this is accompanied by a reduction in social services that can help people in the present day.

The five initiatives explored above and the issues they raise in relation to egalitarian and utilitarian perspectives on distributive justice are briefly summarized on Table 1. In this paper, I have suggested that many of the innovationfacilitating initiatives in the field of RM are being justified by arguments that align with a utilitarian approach to distributive justice. This is a utilitarian approach in which 'value' and 'utility' are largely promissory in nature; it is broadly equated to both future health gains (specifically cures and treatments for unmet clinical need) and future economic gains (a high wealth-generating industry and accompanying employment). In effect, this utilitarian approach to the future is being consolidated in organizational arrangements as innovation-facilitating initiatives are enacted: the formation of the accelerator agencies such as the CCRM and the CGTC is a good example of this. The emerging RM field can be seen as representing the entrenchment of a utilitarian approach to distributive justice.

The emerging field, however, is characterized by a diverse range of stakeholders with varying agendas, and tensions between them are inevitable [5]. Arguments that draw on egalitarian sentiments are also informing the emerging RM field. In some cases, such as in the establishment of ear-marked funding for innovative therapies to address unmet clinical need, these approaches to distributive justice appear to align with utilitarian arguments. In other instances, such as the debates over value-based pricing, egalitarian sentiments appear to conflict with utilitarian arguments. The RM field may represent an entrenchment of a particular utilitarianism, but it also provides spaces for the expression of other sentiments and other values.

Such tensions and conflicts are, for some commentators, cause for optimism. Mittra, for example, is cautiously optimistic that the emerging new health bioeconomy will provide novel opportunities for a more democratic approach to innovation [5]. The new agencies, collaborations and regulatory adjustments that are characteristic of this new ecosystem, Mittra argues, provide spaces for a range of values - such as those relating to public good, national prosperity, commercialization, cost-effectiveness and clinical and social benefit, to be asserted and to guide innovation practices. (This is in contrast to the past, in which biomedical R\&D was dominated by industry and a concern with commercial value, and healthcare governance was dominated by a concern for cost-effectiveness.) If 
this does indeed occur, then innovation in this new health bioeconomy will better align with the values of wider society, and will be better directed toward societal need - both of which are key tenets of the EU Commission's Responsible Research and Innovation framework [44].

It is in this vein that this paper has sought to foreground the issue of distributive justice. As the RM continues to unfold, it is necessary to carefully expose the rationales and values that appear to be shaping the development of innovation-facilitative infrastructures. The apparent dominance of utilitarian arguments raises particular problematics that need to be openly addressed to ensure that the field does indeed align with the values of wider society. The first of these relates to the opportunity cost of devoting resources on the basis of hope: the predicted benefits of RM are by no means guaranteed, and perhaps resources would be better directed to improving the quality of life of people suffering with illnesses in the present day. Scholarship on the political economy of hope illustrates that it is an immensely powerful resource in the organization of biomedical practices [45-48] but just how much value should we invest in hope, and what are the real opportunity costs of redirecting these resources in this way?

Second, it is necessary to continually gauge the palatability of utilitarianism arguments among various stakeholder groups, and to identify ways in which egalitarian-informed arrangements might be established if it is deemed desirable to do so. The debates around the VBP and the decision to retain the QALY-based approach for the time being is an example of this. Other, more general examples include Mazzucato's proposals aimed at ensuring that the tax-payer is fairly compensated for their original investment (via the state) in innovation-facilitation and research. These include the provision of loans that are only repaid if an innovation is commercially successful, and the establishment of specialist development banks [26]. It may be that such initiatives balance an egalitarian sense of justice with the drive to facilitate a potentially health and wealth generating RM industry, in a manner that is widely palatable.

\section{Executive summary}

- Regenerative medicine (RM) has been identified as a strategic priority in many several countries.

- Governments are supporting a range of innovation-facilitating initiatives within the field of RM.

- These initiatives involve establishing new resource distribution arrangements, and thus raise important questions relating to distributive justice.

Theories of distributive justice

- There are multiple positions on the substantive dimensions of distributive justice: egalitarian, utilitarian and libertarian.

- Current healthcare systems tend to represent points at which these different positions are articulated and aligned.

Specific justice issues in RM

- Overall, the emerging RM field appears to involve an entrenchment of a utilitarian approach to resource distribution.

- This is a utilitarianism in which value is promissory in nature and broadly equated with health and national prosperity.

- Some debates surrounding specific initiatives - such as value-based pricing - indicate that egalitarian arguments still carry some authoritative weight.

Conclusion \& future perspective

- It is important to encourage open debate on the values guiding innovation-facilitating initiatives.

- The palatability of utilitarian arguments should be assessed among a range of stakeholders.

- Mechanisms for institutionalizing more egalitarian-informed innovation-facilitating initiatives should be considered.

Financial \& competing interests disclosure

This paper derives from the REGenableMED project (Principle Investigator Andrew Webster) funded by the UK's Economic and Social Research Council (ES/L002779/1). The author has no other relevant affiliations or financial involvement with any organization or entity with a financial interest in or financial conflict with the subject matter or materials discussed in the manuscript apart from those disclosed.

No writing assistance was utilized in the production of this manuscript. 


\section{Open access}

This work is licensed under the Attribution-NonCommercial-NoDerivatives 4.0 Unported License. To view a copy of this license, visit http://creativecommons.org/licenses/by-nc-nd/4.0/

\section{References}

Papers of special note have been highlighted as: $\bullet$ of interest; $\bullet \bullet$ of considerable interest

1. Wainwright S, Williams C, Michael M, Farsides B, Cribb A. From bench to bedside? Biomedical scientists' expectations of stem cell science as a future therapy for diabetes. Soc. Sci. Med. 63(8), 2052-2064 (2006).

2. Regenerative Medicine Expert Group. Building on our own potential: a UK pathway for regenerative medicine. (2014). www.gov.uk/government/uploads/system/uploads/...data/.../build-on-potential.pdf

-• A key document outlining necessary policy changes to support regenerative medicine in the UK.

3. House of Lords. Science and Technology Committee. Regenerative medicine report. (2013). www.publications.parliament.uk/pa/ld201314/ldselect/ldsctech/23/23.pdf

4. Gardner J, Webster A. Accelerating innovation in the creation of biovalue: the cell and gene therapy catapult. Sci. Technol. Human Values 42(5), 925-946 (2017).

5. Mittra J. The New Health Bioeconomy: R\&D Policy and Innovation for the Twenty-First Century. Palgrave Macmillan, Basingstoke, UK (2016).

-. A detailed account of the changing biomedical innovation ecosystem.

6. Gardner J, Webster A. The social management of biomedical novelty: facilitating translation in regenerative medicine. Soc. Sci. Med. 156, 90-97 (2016).

7. Mittra J, Milne C-P. Introduction to translational medicine. Translational Medicine: The Future of Therapy? Mittra J, Milne C-P (Eds). Pan Stanford, Singapore, 1-18 (2013).

8. Beauchamp T, Childress J. Principles of Biomedical Ethics (6th Edition). Oxford University Press, NY, USA (2009).

9. Cohen R. Distributive justice: theory and research. Soc. Just. Res. 1(1), 19-40 (1987).

10. Daniels N. Just Health Care. Cambridge University Press, NY, USA (1985).

11. Department of Health. The NHS Constitution for England. Department of Health, London, UK (2015). www.gov.uk/government/publications/the-nhs-constitution-for-england

12. Faulkner A. Special treatment? Flexibilities and the politics of regenerative medicine's gatekeeping regimes in the UK. Sci. Cult. doi:10.1080/09505431.2017.1300641 (2017) (Epub ahead of print).

13. Claxton K, Sculpher M, Carroll S. Value-based pricing for pharmaceuticals: its role, specification and prospects in a newly devolved NHS. Centre for Health Economics, University of York, York, UK (2011). https://ideas.repec.org/p/chy/respap/60cherp.html

14. Nozick R. Anarchy, State, and Utopia. Basic Books, NY, USA (1974).

15. Christopher A, Caruso D. Promoting health as a human right in the post-ACA United States. AMA J. Ethics 17(10), 958-965 (2015).

16. Webster A. The Global Dynamics of Regenerative Medicine: a Social Science Critique. Palgrave Macmillan, Basingstoke, UK (2013).

17. Lewis G. Regenerative medicine at the global level: current patterns and global trends. In: The Global Dynamics of Regenerative Medicine: A Social Science Critique. Webster A (Ed.). Palgrave, Basingstoke, UK, 18-57 (2013).

18. Gardner J, Higham R, Faulkner A. Webster A. Promissory identities: sociotechnical representations \& innovation in regenerative medicine. Soc. Sci. Med. 174, 70-78 (2017).

19. Gardner J, Webster A, Mittra J. The Entrepreneurial State and the leveraging of life in the field of regenerative medicine. In: Bioeconomies: Life, Technology and Capital in the 21st Century. Pavone V, Goven J (Eds). Palgrave, Basingstoke, UK, 25-47 (2017).

20. The Cell and Gene Therapy Catapult. About Us. https://ct.catapult.org.uk/about-us

21. Thompson K, Foster E. The cell therapy catapult: growing a UK cell therapy industry generating health and wealth. Stem Cells Dev. 22(S1), 35-39 (2013).

22. Mazzucato M. The Entrepreneurial State. Oxford University Press, Oxford, UK (2013).

-• Provides a detailed argument for justifying a more egalitarian approach to innovation. Specific proposals are outlined.

23. Willetts D. Eight Great Technologies.Department of Business, Innovation and Skills. London, UK (2013). www.gov.uk/government/speeches/eight-great-technologies

24. Faulkner A. Law's performativities: shaping the emergence of regenerative medicine through European Union legislation. Soc. Stud. Sci. 42(5), 753-774 (2012).

25. Mahalatchimy A. Reimbursement of cell-based regenerative therapy in the UK and France. Med. Law Rev. 24(2), $234-258$ (2016).

26. Chabannon C, Caunday-Rigot O, Faucher C et al. Accreditation and regulations in cell therapy. ISBT Sci. Ser. 11(S1), $271-276$ (2016). 
27. Ali R, Hollander A, Kemp P, Webster A, Wilkins M. Regulating cell-based regenerative medicine: the challenge ahead. Regen. Med. 9(1), 77-83 (2014).

28. Omidvar O, De Grijs M, Castle D, Mittra J, Rosiello A, Tait J. Regenerative medicine: business models, venture capital and the funding gap. Innogen, Edinburgh, UK (2014).

29. Corbett M, Webster A, Hawkins R, Woolacott N. Innovative regenerative medicines in the EU: a better future in evidence? $B M C$ Med. 15, 49-57 (2017).

30. Faulkner A. Opening the gateway to market and adoption of regenerative medicine? The UK context. Regen. Med. 11(3), 321-330 (2016).

31. Sipp D. Conditional approval: Japan lowers the bar for regenerative medicine products. Cell Stem Cell 16(4), 353-356 (2015).

32. Regalado A. Gene therapy cure has money-back guarantee. MIT Technology Review (2016). www.technologyreview.com/s/602113/gene-therapy-cure-has-money-back-guarantee/

33. Tobita M, Konomi K, Torashima Y, Kimura K, Taoka M, Kaminota M. Japan's challenges of translational regenerative medicine: act on the safety of regenerative medicine. Regenerative Therapy 4, 78-81 (2016).

34. Cryanoski D. Japan to offer fast-track approval path for stem cell therapies. Nat. Med. 19(5), 510 (2013).

35. Mikami K. State-supported science and imaginary lock-in: the case of regenerative medicine in Japan. Sci. Cult. 24(2), 183-204 (2015).

36. Raftery J. Value-based pricing: can it work? BMJ 347, 1-4 (2013).

37. House of Commons Science and Technology Committee. Regenerative medicine: fifteenth report of the session 2016-17. (2017). www.publications.parliament.uk/pa/cm201617/cmselect/cmsctech/275/275.pdf

38. Advanced Therapies Manufacturing Action Plan: retaining and attracting advanced therapies manufacture in the UK. Medicine Manufacturing Industry Partnership. London, UK (2016). www.abpi.org.uk/our-work/mmip/Documents/Advanced-Therapies-Manufacturing-Taskforce-report.pdf

39. Meurgey F, Wille M. The fourth hurdle: reimbursement strategies for regenerative medicine in Europe. In: The Delivery of Regenerative Medicines and Their Impact on Healthcare. Prescott C, Polak J (Eds). CRC Press, London, UK, 337-351 (2010).

40. Accelerated Access Review. Accelerated access review final report: review of innovative medicines and medical technologies. London, UK (2016). www.gov.uk/government/publications/accelerated-access-review-final-report

41. NCoB Novel Neurotechnologies: intervening in the brain. Nuffield Council on Bioethics. London, UK (2013). http://nuffieldbioethics.org/wp-content/uploads/2013/06/Novel_neurotechnologies_report_PDF_web_0.pdf

42. Bailoni M. Regional inequalities and political challenges for healthcare in the United Kingdom. Hérodote 4(143), 162-183 (2011).

43. Salter B. State strategies and the geopolitics of the global knowledge economy: China, India and the case of regenerative medicine. Geopol. 14(1), 47-78 (2009).

44. Salter B, Zhou Y, Datta S. Hegemony in the marketplace of biomedical innovation: consumer demand and stem cell science. Soc. Sci. Med. 131, 156-163 (2015).

45. von Schomberg R. A vision of responsible research and innovation. In: Responsible Innovation: Managing the Emergence of Science and Innovation in Society. Owen R, Bessant J, Heintz M (Eds). Wiley, Chichester, UK, 51-57 (2013).

- A detailed account of responsible research and innovation, and hence, an important resource on justice in innovation.

46. Petersen A, Munsie M, Tanner C, MacGregor C, Brophy J. Stem Cell Tourism and the Political Economy of Hope. Palgrave, Basingstoke, UK (2016).

47. Petersen A. Hope in Health: The Socio-Politics of Optimism. Palgrave Macmillan, Basingstoke, UK (2015).

- A social science analysis of hope and its role in shaping innovation practices in healthcare.

48. Moreira T, Palladino P. Between truth and hope: on Parkinson's disease, neurotransplantation and the production of the 'self'. Hist. Hum. Sci. 18(3), 55-82 (2005). 